\title{
Influence of the Choice of Cultivar and Soil Fertilization on PTE Concentrations in Lactuca sativa L. in the Framework of the Regenerative Agriculture Revolution
}

\author{
Daniela Baldantoni *(D), Alessandro Bellino, Angela Cicatelli (D) and Stefano Castiglione (D) \\ Department of Chemistry and Biology "Adolfo Zambelli", University of Salerno, Via Giovanni Paolo II 132, \\ 84084 Fisciano, SA, Italy; abellino@unisa.it (A.B.); acicatelli@unisa.it (A.C.); scastiglione@unisa.it (S.C.) \\ * Correspondence: dbaldantoni@unisa.it; Tel.: +39-089-969542
}

\section{check for}

updates

Citation: Baldantoni, D.; Bellino, A.; Cicatelli, A.; Castiglione, S. Influence of the Choice of Cultivar and Soil Fertilization on PTE Concentrations in Lactuca sativa L. in the Framework of the Regenerative Agriculture Revolution. Land 2021, 10, 1053. https://doi.org/10.3390/ land10101053

Academic Editors: Ritvik Sahajpal and Alyssa Whitcraft

Received: 13 September 2021

Accepted: 3 October 2021

Published: 7 October 2021

Publisher's Note: MDPI stays neutral with regard to jurisdictional claims in published maps and institutional affiliations.

Copyright: (c) 2021 by the authors. Licensee MDPI, Basel, Switzerland. This article is an open access article distributed under the terms and conditions of the Creative Commons Attribution (CC BY) license (https:/ / creativecommons.org/licenses/by/ $4.0 /)$.

\begin{abstract}
Evaluating the relative weight of the choice of cultivar and soil fertilization on potentially toxic elements (PTEs) accumulation is crucial in promoting informed decisions in the framework of regenerative agriculture. To this end, 11 PTEs $(\mathrm{Cd}, \mathrm{Cr}, \mathrm{Cu}, \mathrm{Fe}, \mathrm{K}, \mathrm{Mg}, \mathrm{Mn}, \mathrm{Na}, \mathrm{Ni}, \mathrm{Pb}, \mathrm{Zn}$ ) were determined in both leaves and roots of six cultivars (Stylist, Xanadu, Aljeva, Bacio, Analena, Vincenzo) of lettuce (Lactuca sativa L.) grown side by side on mineral fertilized or biowaste compost amended soils, under greenhouse conditions. The use of multivariate and linear modelling approaches indicated that the organ and cultivar primarily account for the variability in PTE concentrations. In terms of PTE partitioning between organs, $\mathrm{Cd}$ and $\mathrm{Mg}$ were preferentially accumulated in leaves, whereas $\mathrm{Cu}, \mathrm{Pb}, \mathrm{K}$ and $\mathrm{Zn}$ in roots. As for the cultivar, Xanadu showed the highest concentrations of several PTEs, with Cd reaching concerning levels. Fertilization had a detectable contribution only on $\mathrm{Cd}$ accumulation, slightly increased in leaves by compost. Findings highlight the key role of cultivar choice in guaranteeing food safety and grant the possibility to adopt biowaste compost in regenerative agriculture without concerns about PTE accumulation enhancements in lettuce, but demand a cautionary approach in the case of $\mathrm{Cd}$.
\end{abstract}

Keywords: lettuce cultivars; non-essential elements; nutrients; mineral fertilization; biowaste compost amendment; leaf and root concentrations; circular agriculture; sustainable agriculture

\section{Introduction}

To meet the requirements of the regenerative agriculture revolution, new alternative, intensive and healthy models of agricultural production should be identified. These models need to conjugate high-quantity and high-quality harvest with no harm to the environment, stimulating natural soil regeneration, increasing biodiversity, mitigating climate changes and improving the well-being of people working on land [1,2].

Such an approach to agriculture, developing rapidly in the modern world, is tightly intertwined with the goals of circular economy and sustainable development. Indeed, the focal issues of balancing production and consumption, properly managing natural resources, conserving terrestrial and aquatic ecosystems, and restoring degraded lands [2,3] all fit well within these frameworks. Circular economy specifically addresses these goals through clever and purposely developed means of saving relevant resources, which are not only able to reduce the negative environmental impacts of agricultural activities, but also improve economic performance [4]. Ensuring the sustainability of agricultural land through circular economy imposes the restoration of ecological functioning and stability of agroecosystems, making better use of available resources, contributing to food security, and supporting the health, safety and wellbeing of farmers and farming communities [1,3,4].

In this context, counteracting land degradation is a key objective to ensure a sustainable future [1], above all in the Mediterranean area where the process is particularly intense, and the fragile ecosystems are very sensitive to the exploitation of natural resources [5]. 
Here, agriculture is a major cause of land degradation due to unsustainable management practices that deteriorate the quality of soils, compromising their functions $[3,6]$.

Two out of four main principles of regenerative agriculture, i.e., enhancing soil fertility and diversifying cropping systems [6], have the potential to effectively address this issue and have been largely experienced in the Mediterranean area. In particular, the adoption of organic amendments and the widening of cultivar selections are two of the most common practices promoted in the past few decades [7]. Amendment with biowaste compost has been fostered in the Mediterranean area not only to improve physical, chemical and biological soil properties but also for its undeniable benefits linked to the recycling of organic wastes and the mitigation of climate changes [8-13]. Even if recycling back byproducts from food production, processing and consumption into the food system represent key points of circular and sustainable agriculture [4], concerns regarding the potential introduction of persistent contaminants or the enhancement of their availability to the biota still exist [14-18]. The same applies to the selection of different species and cultivars, able to achieve high yields by enhancing the efficiency of soil utilization, but potentially accumulating large amounts of persistent pollutants, with possible threats for food security and environmental health [19-21].

Despite its promising potential, regenerative agriculture is still at an incipient state of development and farmers, due to the scarce evidence of its short- and long-term effects, are limitedly adopting it [6]. Therefore, more research efforts are required to identify ways to improve sustainable agroecosystems, adopting circular economy practices [4]. With a view of fostering the adoption of regenerative agriculture in Mediterranean agroecosystems, we aimed at deepening the knowledge on the possible impacts of the cultivar choice and soil fertilization on potentially toxic element (PTE) accumulation in Lactuca sativa L., consumed worldwide and the most important salad crop in Mediterranean diet [17,21,22]. In particular, to evaluate the relative weight of the choice of cultivar and soil fertilization on PTE accumulation in lettuce, leaves and roots of six cultivars grown on soils treated with mineral fertilizers or amended with biowaste compost were analysed for $\mathrm{Cd}, \mathrm{Cr}, \mathrm{Cu}$, $\mathrm{Fe}, \mathrm{K}, \mathrm{Mg}$, $\mathrm{Mn}, \mathrm{Na}, \mathrm{Ni}, \mathrm{Pb}$ and $\mathrm{Zn}$ concentrations.

\section{Materials and Methods}

Six cultivars of Lactuca sativa L., Stylist, Xanadu, Aljeva, Bacio, Analena and Vincenzo, widely employed in the Mediterranean diet, were grown under greenhouse conditions at the Frigenti Giuseppe farm $\left(40^{\circ} 47^{\prime} 19^{\prime \prime}\right.$ N, $14^{\circ} 36^{\prime} 16^{\prime \prime}$ E, $20 \mathrm{~m}$ a.s.l.), in San Valentino Torio (Campania region, Southern Italy). The experimental field (about 0.1 ha) was divided into two portions of $500 \mathrm{~m}^{2}$ each. One portion of the field was fertilized (MIN) using an inorganic fertilizer $(6 \% \mathrm{~N}$ and $18 \% \mathrm{P})$ based on soil characteristics and plant requirements. The other portion was amended with biowaste compost (CMP) obtained from the organic fraction of municipal solid waste and urban yard trimmings [19] and furnished by Gesenu S.p.A. (Italy). The amount of compost ( $15 \mathrm{Mg} \mathrm{ha}^{-1}$ dry matter), incorporated into the first $20 \mathrm{~cm}$ depth about 15 days before planting, was determined by previous European experiences pointing to optimal results with doses within the range of $10-30 \mathrm{Mg} \mathrm{ha}^{-1}$ of dry matter [23]. Each half of the experimental field was further divided into 24 plots of $20 \mathrm{~m}^{2}$ each, with four plots assigned to the cultivation of each cultivar, according to a randomized block design.

From each plot, four healthy plants were randomly collected at maturity, transferred in the laboratory, cleaned to remove soil particles and dead material, and separated into leaves and roots. Each of these samples (6 cultivars $\times 2$ fertilization strategies $\times 4$ plots $\times 2$ organs $=96$ samples) was manually pulverised with liquid nitrogen in china mortars, oven-dried at $75{ }^{\circ} \mathrm{C}$ until constant weight and mineralized in triplicate as reported in Baldantoni et al. [24]. PTE concentrations were determined by atomic absorption spectrometry (AAnalyst 100, PerkinElmer, Waltham, MA, USA): $\mathrm{Cd}, \mathrm{Cr}, \mathrm{Cu}, \mathrm{Ni}$ and $\mathrm{Pb}$ concentrations were measured by graphite furnace, whereas $\mathrm{Fe}, \mathrm{K}, \mathrm{Mg}$, $\mathrm{Mn}$, $\mathrm{Na}$ and $\mathrm{Zn}$ concentrations by 
flame. Standard reference material (NIST 1575a Pine Needles [25]) was also analysed in order to verify the accuracy of the data obtained, with recoveries in the range of $93-102 \%$.

Data analysis focused on evaluating the relative weight of the cultivar and soil fertilization in determining PTE concentrations in lettuce. To this end, a variance partition approach was adopted in both the multivariate and the univariate domain, accounting for the differences between leaves and roots by including the organ information in the models. In particular, the former relied on a permutational multivariate analysis of variance model, featuring the Manhattan distance matrix among observations (based on all the PTE concentrations) as the dependent matrix and the cultivar, the fertilization and the organ as predictors. The model was based on $1 \times 10^{5}$ permutations and the breakdown of the variance among predictors was carried out by evaluating the marginal effect of each of them in the full model. In the univariate domain, the contribution of the cultivar and fertilization was evaluated through linear random models for each PTE, including the cultivar, the fertilization and the organ as random terms. The estimation of the variance function, its partition among the predictors, and how each of them affects PTE concentrations was then performed according to the approach of Hoffman and Schadt [26]. All the analyses were carried out within the R 4.1.0 programming environment [27] with the functions of the "vegan" [28] and "variancePartition" [26] packages.

\section{Results and Discussion}

The permutational multivariate analysis of variance highlighted significant differences in non-essential element $(\mathrm{Cd}, \mathrm{Pb})$, micronutrient $(\mathrm{Cr}, \mathrm{Cu}, \mathrm{Fe}, \mathrm{Mn}, \mathrm{Na}, \mathrm{Ni}, \mathrm{Zn})$ and macronutrient $(\mathrm{K}, \mathrm{Mg})$ concentrations (Figures S1-S3) among cultivars $(\mathrm{F}=3.916, p<0.001)$ and between organs $(\mathrm{F}=45.470, p<0.001)$, but not between soil fertilization treatments $(\mathrm{F}=0.526, p>0.05)$.

In terms of the breakdown of the total variance in PTE concentrations, the linear random models highlighted a limited contribution of the cultivar (0-31.3\%), fertilization $(0-5.5 \%)$ and organ (0-55.9\%) factors, with the residuals (38.6-96.6\%) accounting for most of the variance (Figure 1). This is especially the case of $\mathrm{Fe}, \mathrm{K}$ and $\mathrm{Mn}$, with the random factors (remarkably, only one for each element) explaining less than $10 \%$ of the total variance: $3.4 \%$ attributable to the cultivar, $7.0 \%$ attributable to the organ and $5.1 \%$ attributable to the cultivar, respectively for $\mathrm{Fe}, \mathrm{K}$ and $\mathrm{Mn}$ (Figure 2). This pattern holds true for all PTEs with the exception of $\mathrm{Cu}$, where the combined effect of the cultivar $(5.5 \%)$ and organ (55.9\%) accounted for more than $60 \%$ of the total variance (Figure 2). From a practical viewpoint, these results translate into a limited weight associated with the choice of cultivar and fertilization in determining lettuce PTE concentrations. In other words, farmers have great leeway in this respect without overly worrying about the consequences of choosing specific cultivars or fertilization practices on PTE accumulations. This does not mean, however, that the contribution from these choices is negligible, although neither the cultivar nor the fertilization (and the organ) are primary determinants of the variability in PTE concentrations.

In this context, the choice of the cultivar has a higher contribution in respect to the other factors in determining the concentrations of $\mathrm{Cd}(28.3 \%), \mathrm{Cr}(11.4 \%), \mathrm{Fe}(3.4 \%)$, $\mathrm{Mn}(5.1 \%), \mathrm{Ni}(23.8 \%)$ and $\mathrm{Zn}(31.3 \%)$, although it is limited in the case of Fe and Mn (Figure 2). In terms of distribution among cultivars, the highest values of $\mathrm{Cd}$ and $\mathrm{Zn}$ were observed in leaves of Xanadu, the highest values of $\mathrm{Cr}, \mathrm{Fe}, \mathrm{Mn}$ in leaves of Vincenzo and the highest values of $\mathrm{Ni}$ in leaves of Stylist (Figures S1 and S2). These results are only partly in accordance with those obtained by Alexander et al. [29], who found no significant difference in the edible organs of five different lettuce cultivars (Corsair, Little Gem, Lobjoits, Paris Island, Pinokkio) not only for $\mathrm{Cu}$ and $\mathrm{Pb}$, but also for $\mathrm{Cd}$ and $\mathrm{Zn}$. However, Gattullo et al. [17] found significant differences in PTE accumulations in four lettuce cultivars (Aleppo, Maximus, Murai, Patagonia) grown on compost-based substrates and remarked that the choice of cultivar is extremely important to guarantee not only crop yield, but also lettuce quality. 


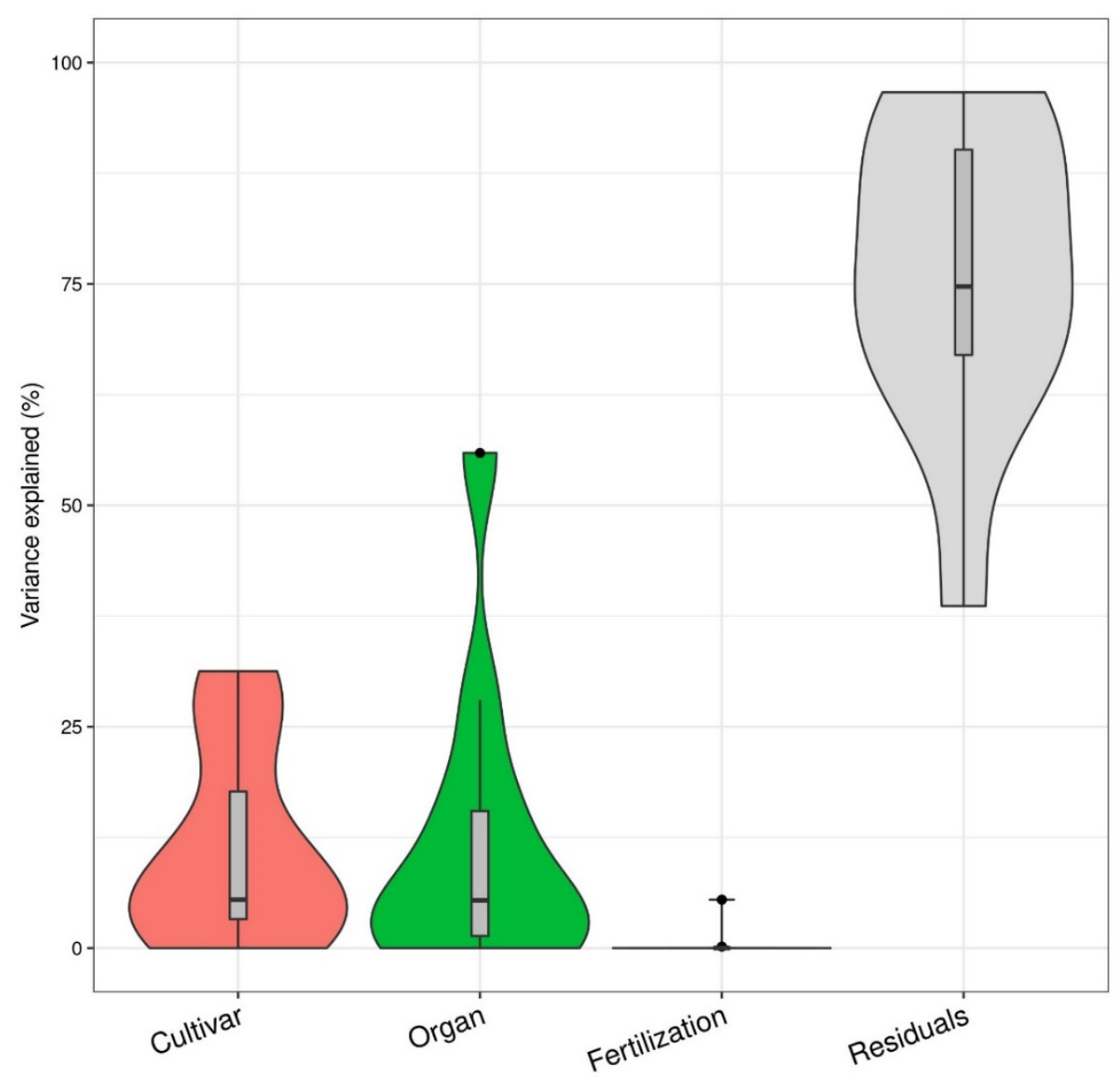

Figure 1. Violin plots representing the distribution of the percentage of explained variance associated with the cultivar (red), the organ (green), and the fertilization (blue) in the linear random models, as well as the model residuals (grey). The rectangular box within each violin represents the interquartile range with its upper and lower whiskers, whereas outliers are represented by black dots.

Soil fertilization practices did not influence micro- and macronutrient concentrations in lettuce (Figure 2), as previously observed also by Luján Soto and co-workers [6] for almond leaves. Only for one of the two non-essential elements analyzed, the linear random models highlighted a contribution (5.5\%), although limited, of soil fertilization (Figure 2), with $\mathrm{Cd}$ concentrations on average highest in the plants grown on soil amended with biowaste compost (Figure S1). These findings can be explained considering our previous results on $\mathrm{Cd}$ concentrations measured in two different Mediterranean soils, in the same region (Campania) and area (Salerno) in which this field trial was conducted [14,15]: during longterm amendments, both total and DTPA-extractable concentrations increased in accordance with the dose of biowaste compost applied. Such increases are usually correlated with enhanced $\mathrm{Cd}$ accumulations in lettuce, as often reported [22]. Nevertheless, in a previous study on Cd accumulation in lettuce [21], we found the highest concentrations in leaves of plants grown on mineral-fertilized soils rather than on biowaste amended soils, confirming that the mobility of a PTE in soil and its transfer to plants depend on several factors [22,30]. In terms of translocation and accumulation of PTEs in lettuce leaves, Cd (Figure S1) reached concentrations on average 6-fold higher than the maximum values reported by Allen [31] for plant material without visible symptoms of dehydration, chlorosis, or necrosis (as also observed by Zorrig et al. [32] and by Celik and Kunene [33]). 


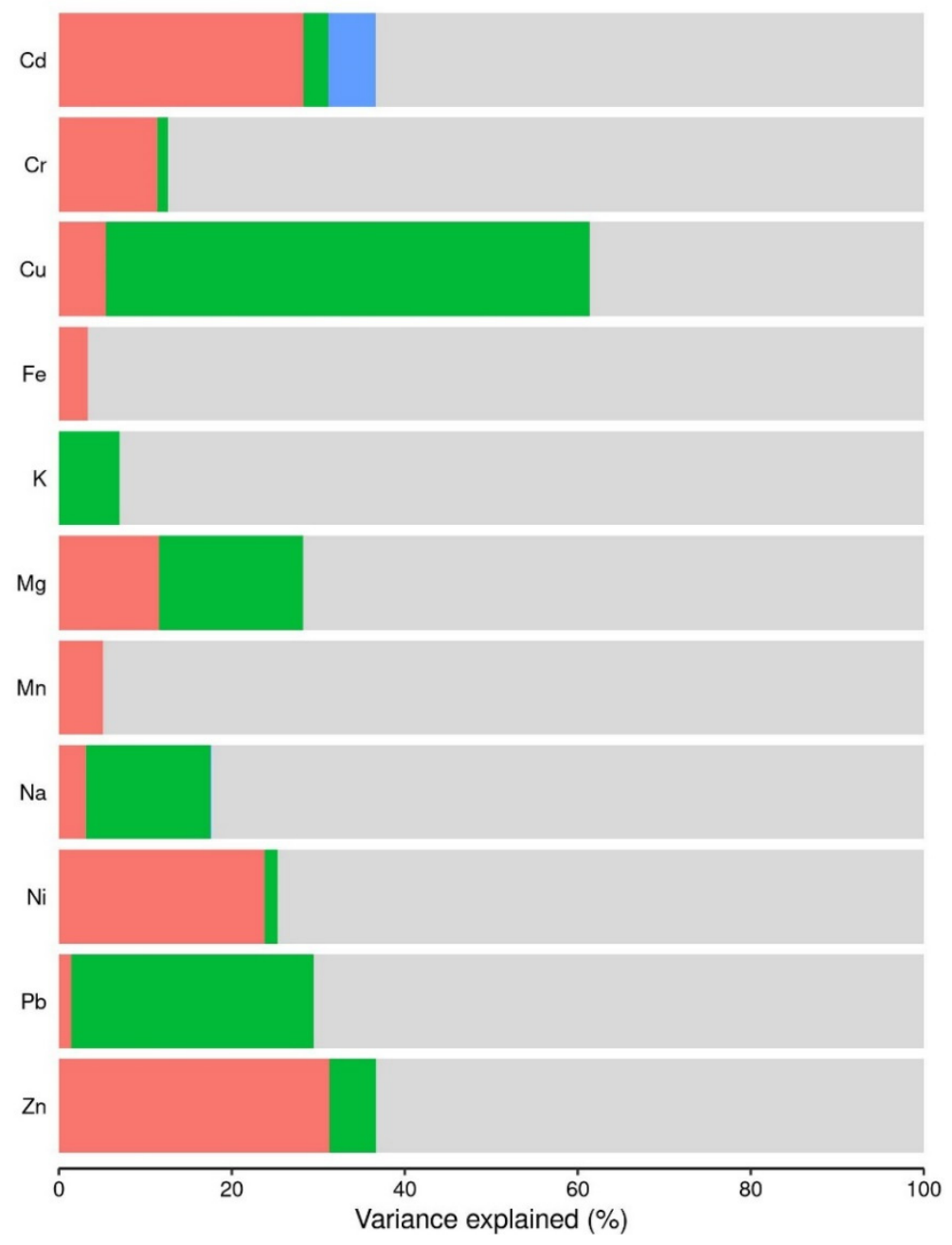

Figure 2. Barplots of the percentage of the variance of each PTE explained by the cultivar (red), the organ (green), and the fertilization (blue) in the linear random models, as well as by the model residuals (grey)

For $\mathrm{Cu}(55.9 \%), \mathrm{K}(7.0 \%), \mathrm{Mg}(16.6 \%), \mathrm{Na}(14.2 \%)$ and $\mathrm{Pb}(28.0 \%)$, the organ had a relatively higher contribution in determining their concentrations (Figure 2), with the highest values observed in leaves in the case of $\mathrm{Mg}$ and in roots in the case of $\mathrm{Cu}, \mathrm{K}, \mathrm{Na}$ and $\mathrm{Pb}$ (Figures S1 and S3). In L. sativa plants, Celik and Kunene [33] also highlighted higher concentrations of $\mathrm{Cu}$ and $\mathrm{Pb}$ (as well as of $\mathrm{Cd}, \mathrm{Cr}, \mathrm{Fe}, \mathrm{Mn}$ and $\mathrm{Zn}$ ) in roots than in leaves; similarly, Jordão et al. [34] found the highest concentrations of $\mathrm{Cu}$ and $\mathrm{Ni}$ in the belowground organs, attributing this behavior to a protection mechanism. These observations put emphasis on the role that PTE bio-geochemical properties have in explaining element peculiar mobility and transfer into the soil-plant system [30].

Considering the average water content $(90 \%)$ of lettuce, Cd reached leaf concentrations comparable, or slightly higher (Xanadu), to that deduced by the EU 420/2011 Regulation [35] on maximum levels for certain contaminants in food, whereas $\mathrm{Pb}$ always had concentrations lower than the threshold, confirming the low mobility of this element in lettuce [22]. By reference, the EU 420/2011 Regulation [35] establishes concentration limits equal to $0.2 \mu \mathrm{g} / \mathrm{g}$ f.w. for $\mathrm{Cd}$ and $0.3 \mu \mathrm{g} / \mathrm{g}$ f.w. for $\mathrm{Pb}$ in leafy vegetables. For $\mathrm{Cd}$, the remark is rather worrying, considering its carcinogenicity [36], the high leaf accumulation capability of lettuce $[29,37,38]$, and the wide consumption of this crop [22,32], above all in the Mediterranean diet [21].

By bringing all the results together in the framework of regenerative agriculture, the preliminary statement on the leeway in choosing the cultivars and fertilization practices 
can be straightforwardly refined. Indeed, although both have limited contribution in determining PTE concentrations in lettuce, their relative weight varies among the elements and can critically affect concentrations in a species with a high accumulation potential. Such an occurrence demands a holistic approach adopting multiple [6] and balanced strategies in meeting the requirements of regenerative agriculture. For example, adopting PTE concentrations as crop performance indicators, soil fertilization with biowaste compost revealed itself as a remarkable strategy, guarantying nutrient concentrations in lettuce comparable to mineral fertilization. If $\mathrm{Cd}$ concentrations are of concern, however, the adoption of compost amendment demands a cautionary attitude, especially when employed with cultivars with enhanced accumulations capabilities. Indeed, even a small contribution from the fertilization may result in products that are unsafe for consumption and do not meet the regulatory requirements. A simple and effective solution in these cases is the use of cultivars with lower accumulation capabilities, as also suggested by Gattullo et al. [17] in their study on lettuce-reasonably general advice that should be tailored, however, to the differential responses that different species may exhibit in relation to the organic amendment [39].

Overall, all these considerations emphasize the need for decisions driven by data, a core requirement for the regenerative agriculture revolution. Our findings contribute to providing foundations for such decisions, promoting the large-scale adoption of regenerative agriculture, especially in Mediterranean agroecosystems, but with the right choices.

\section{Conclusions}

The findings of this research highlight that, despite regenerative agriculture having a strong potential to restore the physical, chemical and biological properties of degraded soils, a careful attitude should be held in crop species and cultivar choice. Although neither the cultivar nor the fertilization are primary determinants of PTE concentrations in lettuce, their contribution cannot be underestimated and should guide the agronomic strategies. This is true for several PTEs, especially for non-essential elements such as $\mathrm{Cd}$, which can reach critical concentrations with wrong combinations of cultivars and fertilization strategies. Overall, however, biowaste compost amendment proved an effective strategy also from the viewpoints of product quality and safety, determining nutrient concentrations comparable to mineral fertilization and only small increases in $\mathrm{Cd}$ concentrations. This drawback can be effectively counteracted by wisely choosing cultivars with lower accumulation potential, a strategy that underpins the need for decisions supported by data in fostering the regenerative agriculture revolution.

Supplementary Materials: The following are available online at https:/ /www.mdpi.com/article/10 .3390/land10101053/s1, Figure S1: mean Cd, Pb, Zn and Cu concentrations ( \pm standard errors) measured in the leaves (white bars) and roots (grey bars) of the six lettuce cultivars grown on soil treated with mineral fertilizers (MIN) and on soil amended with biowaste compost (CMP), Figure S2: mean $\mathrm{Ni}, \mathrm{Cr}, \mathrm{Fe}$ and Mn concentrations ( \pm standard errors) measured in the leaves (white bars) and roots (grey bars) of the six lettuce cultivars grown on soil treated with mineral fertilizers (MIN) and on soil amended with biowaste compost (CMP), Figure S3: mean $\mathrm{Na}, \mathrm{K}$ and $\mathrm{Mg}$ concentrations ( \pm standard errors) measured in the leaves (white bars) and roots (grey bars) of the six lettuce cultivars grown on soil treated with mineral fertilizers (MIN) and on soil amended with biowaste compost (CMP).

Author Contributions: Conceptualization, S.C. and A.C.; methodology, D.B. and A.B.; data acquisition, D.B.; data analysis, D.B. and A.B.; data curation, D.B. and A.B.; resources, S.C.; writing-original draft preparation, D.B.; writing-review and editing, D.B., A.B., A.C. and S.C. All authors have read and agreed to the published version of the manuscript.

Funding: The interdisciplinary research project was conducted with the financial support of the MiPAAF (Ministero Italiano delle Politiche Agricole, Alimentari e Forestali-Progetto OIGA D.M. 18359/7818/09).

Data Availability Statement: The data presented in the study are available in the figures and supplementary material accompanying the present article. 
Conflicts of Interest: The authors declare no conflict of interest.

\section{References}

1. Brown, K.; Schirmer, J.; Upton, P. Regenerative farming and human wellbeing: Are subjective wellbeing measures useful indicators for sustainable farming systems? Environ. Sustain. Indic. 2021, 11, 100132. [CrossRef]

2. Mirzoieva, T.; Heraimovych, V.; Loshakova, Y.; Tripak, M.; Humeniuk, I. Optimization of the sown areas structure as a tool for the development of medicinal crop production on the basis of sustainability and regenerative agriculture. E3S. Web Conf. 2021, 244, 03027. [CrossRef]

3. Trigo, A.; Marta-Costa, A.; Fragoso, R. Principles of sustainable agriculture: Defining standardized reference points. Sustainability 2021, 13, 4086. [CrossRef]

4. Velasco-Muñoz, J.F.; Mendoza, J.M.F.; Aznar-Sánchez, J.A.; Gallego-Schmid, A. Circular economy implementation in the agricultural sector: Definition, strategies and indicators. Resour. Conserv. Recycl. 2021, 170, 105618. [CrossRef]

5. Halbac-Cotoara-Zamfir, R.; Smiraglia, D.; Quaranta, G.; Salvia, R.; Salvati, L.; Giménez-Morera, A. Land degradation and mitigation policies in the Mediterranean region: A brief commentary. Sustainability 2020, 12, 8313. [CrossRef]

6. Luján Soto, R.; Martínez-Mena, M.; Cuéllar Padilla, M.; de Vente, J. Restoring soil quality of woody agroecosystems in Mediterranean drylands through regenerative agriculture. Agric. Ecosyst. Environ. 2021, 306, 107191. [CrossRef]

7. Rhodes, C.J. The imperative for regenerative agriculture. Sci. Prog. 2017, 100, 80-129. [CrossRef]

8. Morra, L.; Pagano, L.; Iovieno, P.; Baldantoni, D.; Alfani, A. Soil and vegetable crop response to addition of different levels of municipal waste compost under Mediterranean greenhouse conditions. Agron. Sustain. Dev. 2010, 30, 701-709. [CrossRef]

9. Baldantoni, D.; Bellino, A.; Morra, L.; Alfani, A. Compost amendment enhances natural revegetation of a Mediterranean degraded agricultural soil. Environ. Manag. 2015, 56, 946-956. [CrossRef]

10. Bellino, A.; Baldantoni, D.; De Nicola, F.; Iovieno, P.; Zaccardelli, M.; Alfani, A. Compost amendments in agricultural ecosystems: Confirmatory path analysis to clarify the effects on soil chemical and biological properties. J. Agric. Sci. 2015, 153, 282-295. [CrossRef]

11. Memoli, V.; De Marco, A.; Baldantoni, D.; De Nicola, F.; Maisto, G. Short- and long-term effects of a single application of two organic amendments. Ecosphere 2017, 8, e02009. [CrossRef]

12. Baldantoni, D.; Saviello, G.; Alfani, A. Nutrients and non-essential elements in edible crops following long-term mineral and compost fertilization of a Mediterranean agricultural soil. Environ. Sci. Pollut. Res. 2019, 26, 35353-35364. [CrossRef] [PubMed]

13. Morra, L.; Bilotto, M.; Baldantoni, D.; Alfani, A.; Baiano, S. A seven-year experiment in a vegetable crops sequence: Effects of replacing mineral fertilizers with Biowaste compost on crop productivity, soil organic carbon and nitrates concentrations. Sci. Hortic. 2021, 290, 110534. [CrossRef]

14. Baldantoni, D.; De Nicola, F.; Alfani, A. Can compost applications affect metal and PAH contents in Mediterranean agricultural soils? Fresenius Environ. Bull. 2010, 19, 1735-1740.

15. Baldantoni, D.; Leone, A.; Iovieno, P.; Morra, L.; Zaccardelli, M.; Alfani, A. Total and available soil trace element concentrations in two Mediterranean agricultural systems treated with municipal waste compost or conventional mineral fertilizers. Chemosphere 2010, 80, 1006-1013. [CrossRef]

16. Baldantoni, D.; Morra, L.; Saviello, G.; Alfani, A. Nutrient and toxic element soil concentrations during repeated mineral and compost fertilization treatments in a Mediterranean agricultural soil. Environ. Sci. Pollut. Res. 2016, 23, 25169-25179. [CrossRef]

17. Gattullo, C.E.; Mininni, C.; Parente, A.; Montesano, F.F.; Allegretta, I.; Terzano, R. Effects of municipal solid waste- and sewage sludge-compost-based growing media on the yield and heavy metal content of four lettuce cultivars. Environ. Sci. Pollut. Res. 2017, 24, 25406-25415. [CrossRef]

18. Picariello, E.; Pucci, L.; Carotenuto, M.; Libralato, G.; Lofrano, G.; Baldantoni, D. Compost and sewage sludge for the improvement of soil chemical and biological quality of Mediterranean agroecosystems. Sustainability 2021, 13, 26. [CrossRef]

19. Cicatelli, A.; Baldantoni, D.; Iovieno, P.; Carotenuto, M.; Alfani, A.; De Feis, I.; Castiglione, S. Genetically biodiverse potato cultivars grown on a suitable agricultural soil under compost amendment or mineral fertilization: Yield, quality, genetic and epigenetic variations, soil properties. Sci. Total Environ. 2014, 493, 1025-1035. [CrossRef]

20. Baldantoni, D.; Bellino, A.; Alfani, A. Soil compost amendment enhances tomato (Solanum lycopersicum L.) quality. J. Sci. Food Agric. 2016, 96, 4082-4088. [CrossRef]

21. Baldantoni, D.; Morra, L.; Zaccardelli, M.; Alfani, A. Cadmium accumulation in leaves of leafy vegetables. Ecotoxicol. Environ. Saf. 2016, 123, 89-94. [CrossRef]

22. Dala-Paula, B.M.; Custodio, F.B.; Knupp, E.A.N.; Palmieri, H.E.L.; Silva, J.B.B.; Gloria, M.B.A. Cadmium, copper and lead levels in different cultivars of lettuce and soil from urban agriculture. Environ. Pollut. 2018, 242, 383-389. [CrossRef] [PubMed]

23. Haber, N.; Deller, B.; Flaig, H.; Schulz, E.; Reinhold, J. Sustainable Compost Application in Agriculture. ECN INFO PAPER 2008, 2 , $1-36$.

24. Baldantoni, D.; Ligrone, R.; Alfani, A. Macro- and trace-element concentrations in leaves and roots of Phragmites australis in a volcanic lake in Southern Italy. J. Geochem. Explor. 2009, 101, 166-174. [CrossRef]

25. Mackey, E.; Becker, D.; Oflaz, R.; Greenberg, R.; Lindstrom, R.; Yu, L.; Wood, L.; Long, S.; Kelly, W.; Mann, J.; et al. Certification of NIST Standard Reference Material 1575a Pine Needles and Results of an International Laboratory Comparison. Available online: https:/ / www.nist.gov/system/files/documents/srm/SP260-156.pdf (accessed on 11 September 2021). 
26. Hoffman, G.E.; Schadt, E.E. variancePartition: Interpreting drivers of variation in complex gene expression studies. BMC Bioinform. 2016, 17, 483. [CrossRef]

27. R Core Team. R: A Language and Environment for Statistical Computing; R Foundation for Statistical Computing. Vienna, Austria, 2021. Available online: https:/ / www.R-project.org (accessed on 11 September 2021).

28. Oksanen, J.; Blanchet, F.G.; Friendly, M.; Kindt, R.; Legendre, P.; McGlinn, D.; Minchin, P.R.; O’Hara, R.B.; Simpson, G.L.; Solymos, P.; et al. Vegan: Community Ecology Package. R Package Version 2.5-7. 2020. Available online: https://CRAN.R-project.org/ package=vegan (accessed on 11 September 2021).

29. Alexander, P.D.; Alloway, B.J.; Dourado, A.M. Genotypic variations in the accumulation of $\mathrm{Cd}, \mathrm{Cu}, \mathrm{Pb}$ and $\mathrm{Zn}$ exhibited by six commonly grown vegetables. Environ. Pollut. 2006, 144, 736-745. [CrossRef] [PubMed]

30. Kabata-Pendias, A.; Pendias, H. Trace Elements in Soils and Plants, 3rd ed.; CRC Press: Boca Raton, FL, USA, 2001.

31. Allen, S.E. Chemical Analysis of Ecological Materials, 2nd ed.; Blackwell Scientific Publications: Oxford/London, UK, 1989.

32. Zorrig, W.; El Khouni, A.; Ghnaya, T.; Davidian, J.-C.; Abdelly, C.; Berthomieu, P. Lettuce (Lactuca sativa): A species with a high capacity for cadmium (Cd) accumulation and growth stimulation in the presence of low Cd concentrations. J. Hortic. Sci. Biotechnol. 2013, 88, 783-789. [CrossRef]

33. Celik, H.; Kunene, S.S. Effects of cadmium and chicken manure on dry weight and some heavy metal amounts for healthy lettuce (Lactuca sativa L.) consumption. Fresenius Environ. Bull. 2021, 30, 4787-4797.

34. Jordão, C.P.; de Andrade, R.P.; Cotta, A.J.B.; Cecon, P.R.; Neves, J.C.L.; Fontes, M.P.F.; Fernandes, R.B.A. Copper, nickel and zinc accumulations in lettuce grown in soil amended with contaminated cattle manure vermicompost after sequential cultivations. Environ. Technol. 2013, 34, 765-777. [CrossRef]

35. Regolamento UE 420/2011 Della Commissione del 29 Aprile 2011 Che Modifica il Regolamento (CE) n. 1881/2006 Che Definisce i Tenori Massimi di Alcuni Contaminanti Nei Prodotti Alimentari. Available online: https:/ / eur-lex.europa.eu/legal-content/IT/ TXT/PDF/?uri=CELEX:32011R0420\&from=PL (accessed on 11 September 2021).

36. International Agency for Research on Cancer. IARC Monographs on the Evaluation of Carcinogenic Risk to Humans; IARC: Lyon, France, 2011.

37. Jordão, C.P.; Fialho, L.L.; Cecon, P.R.; Matos, A.T.; Neves, J.C.L.; Mendonça, E.S.; Fontes, R.L.F. Effects of Cu, Ni and Zn on lettuce grown in metal-enriched vermicompost amended soil. Water Air Soil. Pollut. 2006, 172, 21-38. [CrossRef]

38. Waheed, H.; Ilyas, N.; Raja, N.I.; Mahmood, T.; Ali, Z. Heavy metal phyto-accumulation in leafy vegetables irrigated with municipal wastewater and human health risk repercussions. Int. J. Phytoremedia. 2019, 21, 170-179. [CrossRef] [PubMed]

39. Siddiqui, H.J.; Gul, S.; Kakar, A.R.; Shaheen, U.; Rehman, G.B.; Khan, N.; Samiullah. Poultry manure as an organic fertilizer with or without biochar amendment: Influence on growth and heavy metal accumulation in lettuce and spinach and soil nutrients. Phyton 2021, 90, 651-676. [CrossRef] 